\title{
G6PD wt Allele
}

National Cancer Institute

\section{Source}

National Cancer Institute. G6PD wt Allele. NCI Thesaurus. Code C50879.

Human G6PD wild-type allele is located within Xq28 and is approximately $37 \mathrm{~kb}$ in length. This allele, which encodes glucose-6-phosphate 1-dehydrogenase protein, is involved in the production of $\mathrm{NADPH}$, an electron donor in both reductive biosynthetic reactions and protection against oxidizing agents. Certain allelic variants of the G6PD gene cause G6PD protein deficiency which, in turn, is associated with acute hemolysis, chronic granuloma, neonatal jaundice, and severe non-spherocytic hemolytic anemia. 